\title{
SUSTAINABLE DEVELOPMENT OF AGRICULTURE IN KARST AREAS, SOUTH CHINA ${ }^{1}$
}

\author{
Song Linhua
}

\begin{abstract}
The exposed carbonate rocks aged from Sinian to Mid-Triassic Periods cover an area of $500,000 \mathrm{Km}^{2}$ in south-west China. In karst areas with spectacular landscapes characterized by magnificent tower karst and conical karst, rare surface drainage systems and prevalent subsurface drainage systems, the environment is ecologically very fragile. The rapid increase of population, over deforested and cultivated lands, worsted the ecological system, causing a higher frequency of draught, flood and various disasters, backward economic development, low living standard of the people.

In order to improve the sustainability of the agriculture the experience shows that the following operations should be adopted: (1) serious control of the population increase, emigration, extra labours and improvement of the environmental education of the local inhabitants; (2) terracing of the slopes (shi jala di) as to improve the cultivated land quality, to preserve the water, soil and fertiliser and ameliorate the effective utilisation of the land; (3) development of new rural energies such as the solar energy and gas energy, and expansion of the saving-fuel stoves to reduce the load of bio-energy; (4) reforestation and bounding the hills and mountains; the ecological, economic and fuel forests model has been developed in fengcong-depression areas: the tree species with high ecological, economical and energetic characteristics, should be chosen, such as the bamboo, wild grapes, Sapium rotundifolium etc.; (5) better utilisation of the rain water and karst water resource to solve the water supply problems.

The karst landscape is well developed in the $500,000 \mathrm{~km}^{2}$ carbonate terrain in Yunnan, Guizhou, Guangxi, west Hunan and south Sichuan provinces in south-west China, where 100 million habitants live (Song, 1997). The large population and its high density, serious deforestation, over-cultivation and fragile ecological system make the environmental problems very serious and about $30,000,000$ people are now very poor.

This paper describes the measures to improve the ecological and sustainable development of the agriculture in the karst areas.
\end{abstract}

KEY WORDS: South China, human impact on karst, sustainable development.

\section{Geomorphological characteristics}

The karst region of South China, $500,000 \mathrm{~km}^{2}$ large, is situated in the tropical and subtropical monsoon zones; its annual average temperature is $15-20^{\circ} \mathrm{C}$, with a maximum of $22^{\circ} \mathrm{C}$. The annual mean precipitation ranges from 1000 to $1600 \mathrm{~mm}$, the

\footnotetext{
${ }^{1}$ This research project was financially supported by the National Natural Science Foundation of China (No. 49471008) and Applied Science Foundation of Yunnan Province (1988-1990). During the research, the Xichou County Government, Yunnan Province and Dahua County Government gave great support. The authors would thank Mr. Liu Hong, Zhang Fan, Chen Xiaoping, Yunnan Institute of Geography; thanks are also given to Mr. Su Jiewu, Liang Wanyiao and Lan Huaxin for their good associated work.
} 
maximum being $2500 \mathrm{~mm}$. Under the effect of monsoon climate, the regimes of temperature and precipitation are synchronous, hot and wet in summer, cool and dry in winter.

The carbonate rocks, with a thickness ranging from 5000 to $7000 \mathrm{~m}$ (Zhou Huixian, 1965), aged from Sinian to Mid-Triassic Periods and have been intensively faulted and folded by different tectonic phases. The SN, EW, NE, NNE and NW sets of faults and fractures are well developed and control the hydro-geomorphology framework.

The main types of complex karst features are the "fenglin plain", "fenglin basin", fengcong depressions", "fengcong basin", "fengcong canyon". The individual features are tower, column and conic hills, stone forest, stone teeth, karren, depression, polje, basin, sinkhole, funnel, solutional pot, top window, cave, speleothem, spring, underground river etc. (Chen Suopeng, 1954; Zeng Caoxian, 1960, 1964). In the area the three outstanding karst monuments are the Guilin tower karst, the Fengcong type deep depressions in Qibailong, Dahua, Guangxi, and the Lunan Stone Forest in Yunnan (Ford, 1997).

The intermittent intensive tectonic movement caused not only the uplifting of the Himalayan chain, but also revived the old faults in the southern China and stimulated the karst development also in a vertical dimension. Series of rejuvenated geomorphologic features have been created (Song, 1986). The geomorphologic sequence from the water divides to the main surface river (Wujiang River that is the local drain base) in a belt of $0-15 \mathrm{~km}$ which consists of fenglin basins, fenglin depressions, fengcong depressions including the normal and rejuvenated depressions and the hanging depressions; valleys and streams often appear by the river (Fig. 1) (Yang et al, 1976; Yang, 1988).

In the geomorphological profile from the Tibet plateau at the altitude 4000-5000 $\mathrm{m}$ above the sea level (a.s.l.) to the Guangxi basin about 100-300 $\mathrm{m}$ a.s.l. four main

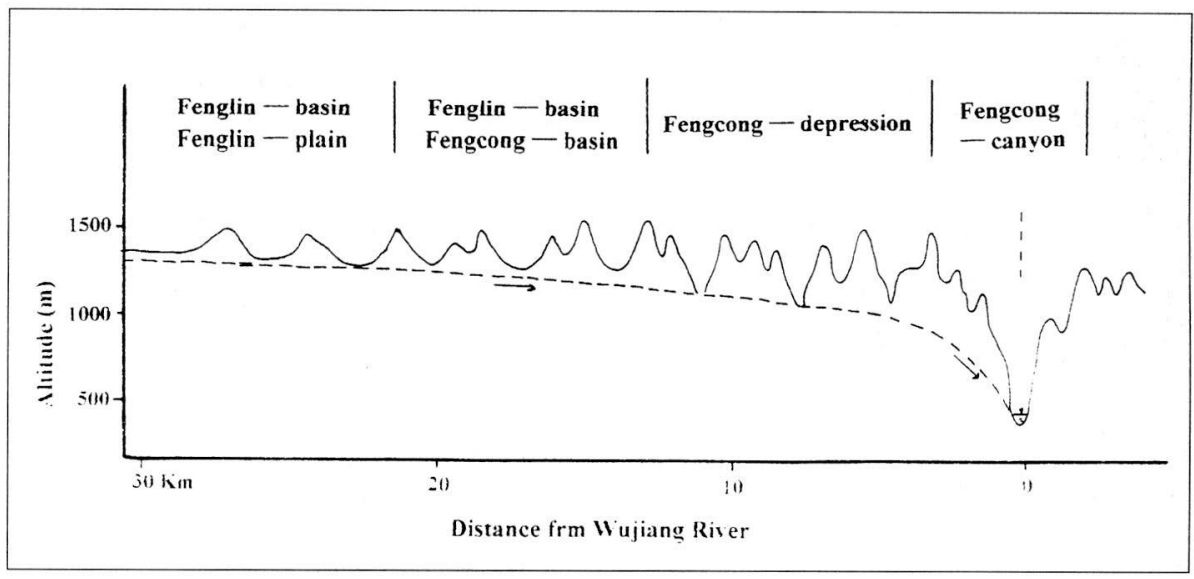

Fig.1 - Karst geomorphological series in Guizhou Plateau. 
geomorphological levels are recognisable: the Tibetan-Qinghai plateau, the Yunnan plateau (1500-2500 $\mathrm{m}$ a.s.1.), the Guizhou plateau (900-1500 $\mathrm{m}$ a.s.1.) and the Guangxi fenglin and residual karstic hill plain. The conical karst landscape (conical fenglin) developed on the Yunnan and Guizhou plateaux, the fengcong - depression including the normal and rejuvenated depressions are distributed in the slope zones between the last two plateaux.

On the karstic plateaux, the surface rivers and ground water drainage systems generally with the hydraulic gradient of $1-5^{\circ}$ are well developed. The groundwater is very close to the ground surface. The natural karst lakes are well developed on the plateaux such as Puheizhai lake, $10 \mathrm{~km}^{2}$ large, in Qiubei, Yunnan (Fig. 2).

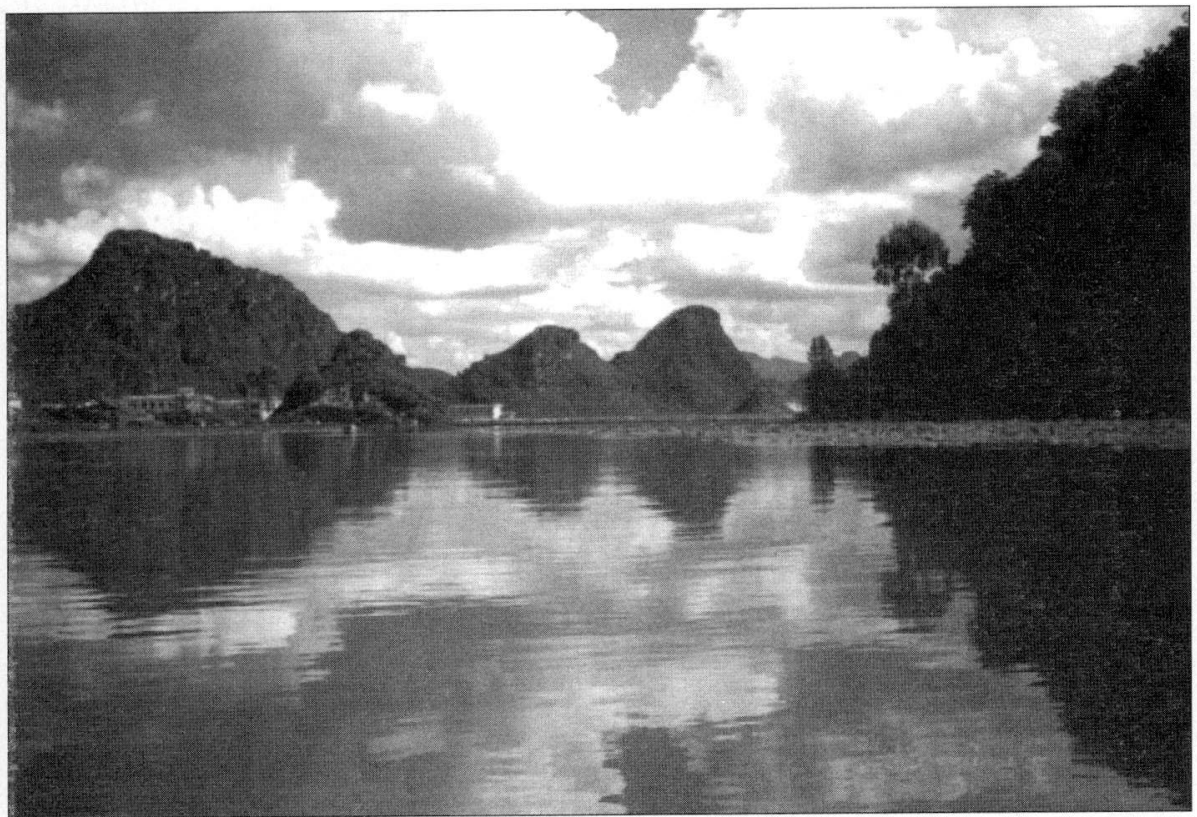

Fig. 2 - Puzhihei karst lake on the Yunnan Plateau, Quibei.

In the fengcong-depression region, the surface and rainfall waters quickly flow into the underground drainage system through the sinks and solutional fissures. The vadose zone is very thick, generally, the groundwater is tens meters beneath the bottoms of the shallow depressions and hundreds of meters under the deep depressions. Each depression constitutes an independent system. The water is collected from the conical peaks and swallowed in the depressions. Simple underground channels are developed between the depressions along the hydraulic gradient direction. In flood conditions some springs originate creeks flowing from the upstream side to the downstream side of the large depressions. In the region, the ground surface water is very rare if there is no the relative aquiclude. The natural resources are lacking and the environmental problems become more and more serious in the region. 


\section{Ecological and environmental problems}

In the karst areas, the population is increasing by the annual natural growth rate of $1.3-2.0 \%$. The average population density reached $159 \mathrm{p} / \mathrm{km}^{2}$, with a maximum of $280 \mathrm{p} / \mathrm{km}^{2}$. The ratio between the population and the cultivated land becomes very high. In the "fengcong" depression region in Dahua County, the cultivated land pro capite is now less than 0.007 ha (including the land with a slope $>15^{\circ}$ ). The shortage of cereals and income forced the farmers to enlarge the farmland on the steep slope (Table 1). The farmland seems hanging on the steep slope of karst peaks. The forest coverage rate decreased from $30-40 \%$ before 1949 to less than 5\% even $1.2 \%$ on the exposed karst hills at the present (Su Zhongming, 1993).

\begin{tabular}{|l|c|c|c|c|c|c|c|}
\hline Slope & $\mathbf{< 6}^{\circ}$ & $\mathbf{6 - 1 5}^{\circ}$ & $\mathbf{1 5 - 2 5}^{\circ}$ & $\mathbf{2 5 - 3 5}^{\circ}$ & $\mathbf{3 5 - 4 5}^{\circ}$ & $\mathbf{> 4 5}^{\circ}$ & Total \\
\hline Cultivated area (ha) & 81.3 & 372.2 & 15968 & 39333 & 37972 & 20377 & 114037 \\
\hline \% of the total lands & 0.013 & 0.326 & 14.00 & 34.49 & 33.30 & 17.87 & 100 \\
\hline
\end{tabular}

Table 1 -The slope of cultivated lands in Dahua County, Guangxi.

The investigation in 26 counties in Guizhou shows a serious soil erosion that took place in an area of $13,500 \mathrm{~km}^{2}$, about $20 \%$ of the total surface. The accelerated soil erosion in Heizhang, Shuicheng, Wangmou, Ziyun and Leishan counties is affecting the $47 \%$ of the total area. In Heizhang county, accelerated soil erosion involves the $57.6 \%$ of the total area; erosion rate reaches $2.1 \mathrm{~mm} / \mathrm{a}$. In the period of 1957-1981, the rocky land increased 467 ha per year. In $70 \%$ of the farms in Ziyun County the cultivated fields are on steep karst hills and the soil erosion area covers $59 \%$ of the total. 17,300 ha of the rocky land, about $51 \%$ of the total area, increased from 1974 to 1982 . Now the farmland is mostly degraded and rocky desertified.

After a heavy rain, the surface runoff transports soil, debris and organic materials down to the depressions and basins. The soil flow on the slope often damages the farmland in the basins and large depressions. In 1988, near 0.8 ha of rice field was covered by $1-1.5 \mathrm{~m}$ of debris from the hills near Xinjie, and $10 \%$ of rice and corn field have been risked by the mudflow during the rainy seasons in Bangguo, Xizhou County. In the county, the storage capacity of reservoirs has been reduced about 30$50 \%$, and some of them have completely lost their capacity. There are 375 depressions flooded 15-90 days each year. The frequency and intensity of the flood and draught hazards have been increased (Table 2 and table 3 ).

\begin{tabular}{|l|c|c|c|c|c|c|c|c|c|}
\hline Periods & \multicolumn{3}{|l|}{ Serious flood } & \multicolumn{3}{l|}{ Serious draught } & \multicolumn{3}{|c|}{ Serious flood \& draught } \\
\hline & Times & Freq. (\%) & Reap.(a) & Times & Freq. (\%) & Reap.(a) & Times & Freq. (\%) & Reap. (a) \\
\hline $1301-1957$ & 8 & 1.22 & 82 & 11 & 1.67 & 60 & - & - & - \\
\hline $1958-1979$ & 6 & 27.27 & 4 & 9 & 40.9 & 2.5 & 1 & 4.55 & 22 \\
\hline $1980-1986$ & 3 & 42.48 & 2.5 & 4 & 57.14 & 2 & 2 & 28.57 & 4 \\
\hline
\end{tabular}

Notes: Freq. $=$ Frequency; Reap. $=$ Reappearance .

Table 2 - The frequency and reappearance of natural hazards in Xichou County, Yunnan Province. 


\begin{tabular}{|l|c|c|c|c|}
\hline Periods & $\mathbf{1 9 5 8 - 1 9 6 0}$ & $\mathbf{1 9 6 1 - 1 9 7 0}$ & $\mathbf{1 9 7 1 - 1 9 8 0}$ & $\mathbf{1 9 8 1 - 1 9 8 9}$ \\
\hline date & & $31 / 7 / 1969$ & $17 / 8 / 1971$ & $24 / 7 / 1986$ \\
\hline Max.rainfall(mm) & $<82$ & 88.9 & 95.0 & 135.1 \\
\hline
\end{tabular}

Table 3 - The maximum rainfall a day from 1958 to 1989 in Xichou County.

The storage capacity of the karst aquifer has been greatly reduced. For example, the designed capacity of the Nanquo irrigation system was $0.8 \mathrm{~m}^{3} / \mathrm{s}$ with the lowest discharge of Nanquo spring in 1958. With the decrease of forest coverage from $40 \%$ to $3.8 \%$ in the karst terrain, the lowest discharge of Nanque spring has been reduced to $0.18 \mathrm{~m}^{3} / \mathrm{s}$ in early 80 's and $0.15 \mathrm{~m}^{3} / \mathrm{s}$ at present. By the 90 's, $75 \%$ of 120 pumping stations built in early 60's has lost their functions as the ground water level fell down or the springs completely dried out in the dry seasons. In Qibailong Fengcongdepression region, there were a lot of fissure springs around the depressions in the 40 's early 50's when the forest coverage was over $40 \%$. After several serious tree clearings, the forest coverage reduced to $4 \%$, and most springs have disappeared since 80 's. The depressions became very dry. At present, 12,000 of a total of 16,500 people are short of water supply.

It is very difficult to build reservoirs and develop other water projects in the depressions also because the subsoil karst and epikarst are well developed. Since 1958, in Guangxi province 1252 reservoirs have been built in the karst basins and depressions, but over $60 \%$ are dry (Table 4).

\begin{tabular}{|c|c|c|c|c|c|c|}
\hline Regions & $\begin{array}{l}\text { Reservoir } \\
\text { Numbers }\end{array}$ & $\begin{array}{l}\text { Designed } \\
\text { Capacity } \\
\left(\mathrm{x} 10^{6} \mathrm{~m}^{3}\right) \\
\end{array}$ & $\begin{array}{l}\text { Designed } \\
\text { irrigating } \\
\left(\times 10^{3} \mathrm{ha}\right) \\
\end{array}$ & $\begin{array}{l}\text { Practical } \\
\text { irrigating } \\
\left(\mathrm{x} 10^{3} \mathrm{ha}\right) \\
\end{array}$ & $\begin{array}{l}\text { Practical } \\
\text { Capacity } \\
\left(\times 10^{6} \mathrm{~m}^{3}\right) \\
\end{array}$ & $\begin{array}{l}\text { Leakage } \\
\text { reservoir } \\
\text { (N) } \\
\end{array}$ \\
\hline Nanning & 658 & 16.4 & 193 & 143 & 211 & 447 \\
\hline Liuzhou & 279 & 7.8 & 80 & 52 & 191 & 88 \\
\hline Heci & 147 & 3.8 & 25 & 16.0 & 99 & 48 \\
\hline Baice & 64 & 4.4 & 23 & 15.0 & 46 & 18 \\
\hline Wuzhou & 45 & 1.1 & 12 & 9.0 & 29 & 16 \\
\hline Guilin & 33 & 1.0 & 13 & 9.8 & 20 & 13 \\
\hline Yuelin & 26 & 0.9 & 10 & 5.7 & 12 & 14 \\
\hline Total & 1252 & 35.4 & 356 & 250.5 & 608 & 644 \\
\hline
\end{tabular}

Table 4 - The leakage reservoirs in depressions and basins in Guangxi.

\section{Improvement of ecology and sustainable development in karst areas.}

The improvement of ecological system in the karst areas is the key factor for a sustainable development of the economy. The principal measures should be taken as follows:

\subsection{Reduction of extra population and increase of the population quality}

The over growth of population is overloading the fragile ecological system in the karst fengcong - depression areas, for instance in Qibailong, Dahua county. 16525 
people live on $14030 \mathrm{mu}$ of farmland, in which, $13867 \mathrm{mu}$ are dry land with the mean specific cereals yield of $96 \mathrm{~kg} / m u^{(2)}$. Each person only gets $81.5 \mathrm{~kg}$ grain per year. Based on the living standard, the grain pro capite must be $200 \mathrm{~kg} / \mathrm{a}$, that grain capacity of $14030 \mathrm{mu}$ land might feed about 6500 people, the rest 9000 people will be the extra. To improve the ecological system and help the people to reduce the poverty, the government must control the family planning and favour the emigration of the extra-population; now 500 people have moved to Guangdong, Hainan and east Guangxiand, 963 people to the developing region near the county town.

The population education is very low; for example, the number of the illiterates and semi-literates older than 12 years represents $50 \%$ or more of the total population in karst area. The farmers are very reluctant to accept the new knowledge and cultivation techniques and to improve the rural economy; they prefer to keep their traditional technology. The investigation shows that the annual income of educated farmers is 2 times or more higher than that of the uneducated farmers. In order to promote a sustainable development of the agriculture, it should be made a great effort to increase the number of educated people.

\subsection{Establishment of different forest models on bare karst hills}

To improve the ecological system on the bared karst hills, a reforestation model has been developed for the fengcong - depression region in Xichou County, Yunnan (Fig. 3).

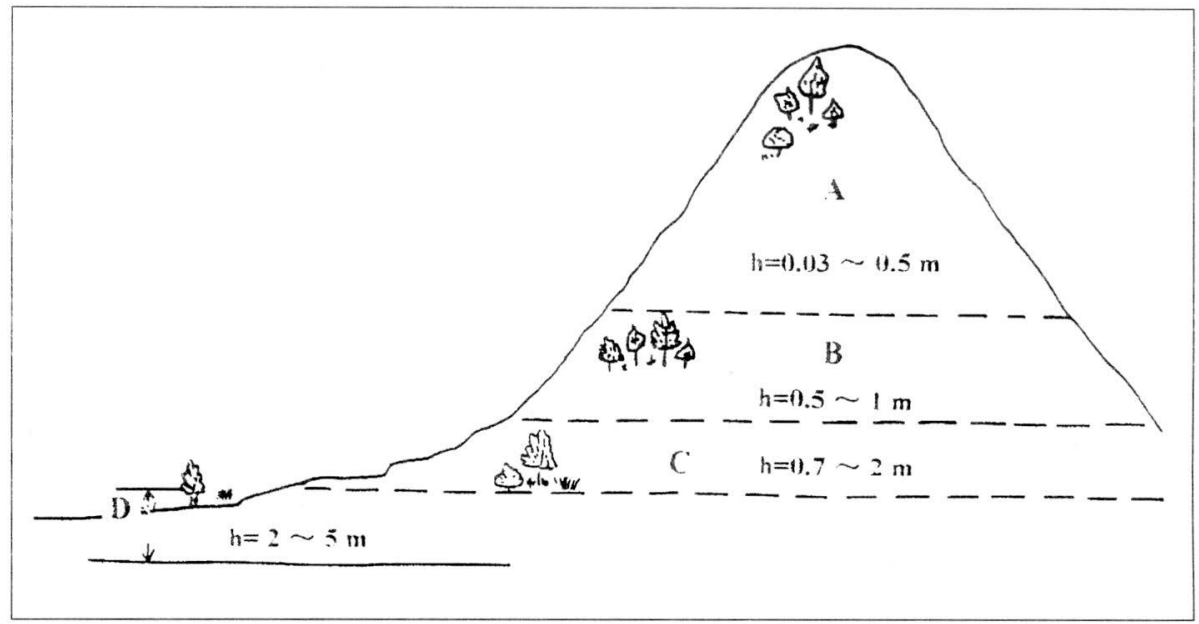

Fig. 3 - Forest model in fengcong-depression region in Xichou. A: Forest for water resource and slope protection; B: Forest for economy and feul; C: Forest for protection of terrace lands and economy; D: Guarden economic forest; Dh: soilthickness

\footnotetext{
${ }^{2}$ The $\mathrm{mu}$ is the basic and traditional area unit in China, $1 \mathrm{mu}=666 \mathrm{~m}^{2}$ or $1 \mathrm{mu}=0.0667$ ha $(1 \mathrm{ha}=15 \mathrm{mu})$.
} 
The Sapium rotundifolium Hemsl is the best economic and ecological tree species (Zhang et al, 1993). It can grows $1 \mathrm{~m}$ a year on the bared karst with less soil in the fissures and can be used as fuel, the leaves as pesticide, the fruits as raw materials for chocolate, the wood is also good for the ship building.

Bamboo and wild grapes are good shrubs to be planted on the Fengcong hills in Guangxi. Bamboo may grow in the fissure with soil, later the roots will hold the rock and grows on the rock. It may fix leaves and sediments on the rock blocks by the roots. The bamboo is good material for processing and building industries, bamboo shoots are good food. The wild grapes are not only for ecological improvement, but also the material to make wine and drinks.

\subsection{Improvement of the land quality and return of high slope land to forest}

Table 5 shows that the terrace lands are much better than other types of lands, while it only can be built on the gentle slope. The Shi Jala di ${ }^{3}$ land has a high content of organic matters, may conserve the soil, water and fertiliser and benefit to management of farm in comparison with steep slope lands. If it possible Shi Jiala di

\begin{tabular}{|c|c|c|c|c|c|}
\hline \multicolumn{2}{|c|}{ Land types } & Flat lands & Terrace lands & Slope lands & Shi Jala di lands \\
\hline \multicolumn{2}{|c|}{$\mathrm{CaCO}_{3}$ content $(\%)$} & 1.0035 & 1.3269 & & 1.9945 \\
\hline \multicolumn{2}{|c|}{$\mathrm{pH}$ value } & 7.60 & 7.63 & & 7.71 \\
\hline \multicolumn{2}{|c|}{ Organic contents $(\%)$} & 3.1416 & 4.2158 & & 5.3583 \\
\hline \multirow[t]{2}{*}{$\mathrm{N}$} & Total $(\%)$ & 0.1275 & 0.1696 & & 0.2356 \\
\hline & Alkalinity $(\%)$ & 0.0109 & 0.0128 & & 0.0192 \\
\hline \multirow[t]{2}{*}{$\mathrm{P}$} & Total $\mathrm{P}_{2} \mathrm{O}_{5} \%$ & 0.0901 & 0.1062 & & 0.1012 \\
\hline & Valuableppm & 9.2654 & 7.5957 & & 4.3385 \\
\hline \multirow[t]{2}{*}{$\mathrm{K}$} & Total $\mathrm{K}_{2} \mathrm{O} \%$ & 0.8026 & 0.9276 & & 0.6016 \\
\hline & Valuableppm & 89.0551 & 81.9100 & & 63.0495 \\
\hline \multicolumn{2}{|c|}{ Slope } & $<8^{\circ}$, & $<8^{\circ}$, & $8-25^{\circ}$, & $25-45^{\circ}$, \\
\hline \multicolumn{2}{|c|}{ Soilthickness (mm) } & $>100$ & $40-100$ & $40-100$ & $10-40$ \\
\hline \multicolumn{2}{|c|}{ Exposed rocks } & $<10 \%$ & $<10 \%$ & $10-40 \%$ & $40-60 \%$ \\
\hline \multicolumn{2}{|c|}{ Soil erosion } & very low & light & medium & medium \\
\hline \multicolumn{2}{|c|}{ Corn yields (Kg/muain ) } & $>250$ & $>250$ & $150-250$ & $<150$ \\
\hline
\end{tabular}

Table 5 - Land and properties of farmlands in karst fengcong-depression area of Xichou County, Yunnan

should be enlarged also in form of small terraces (Fig. 4). If the land is sloping $25^{\circ}$ or less, it is better to arrange it as terrace land (Fig. 5); when the slope is steeper than $25^{\circ}$, the land should be reforested.

${ }^{3}$ Shi Jala di is the local name, means the small piece of farmland surrounding by the stone walls or the fissure and the space filled with soil among the rocks may be farmed and also named as the Shi Jala di. 


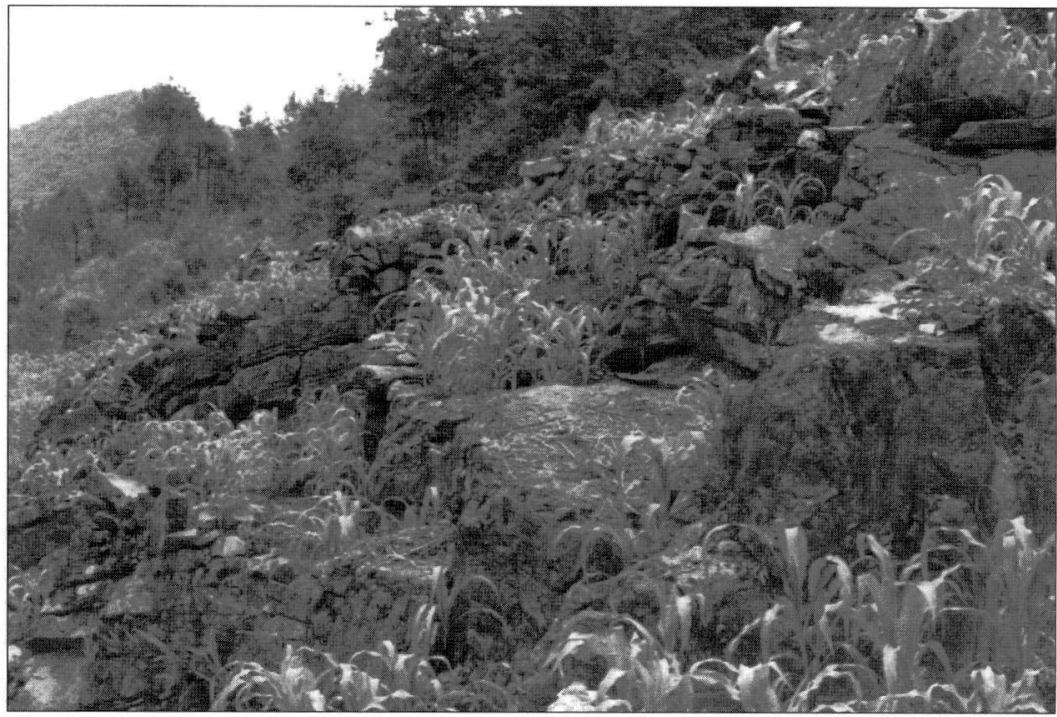

Fig. 4 - Shi Jala di land on karst hill, Xichou, Yunnan.

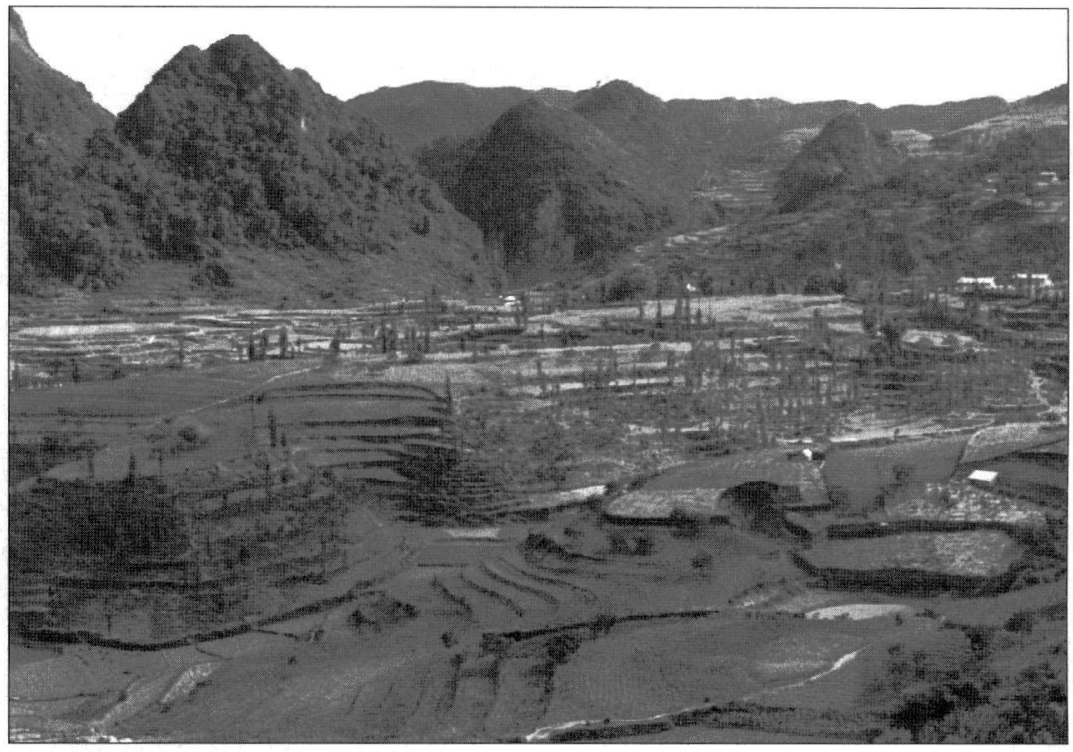

Fig. 5 - The terrace land in karst area, Xichou, Yunnan.

The strong filtration makes the land in karst depression very poor and short of some elements like $\mathrm{P}, \mathrm{B}, \mathrm{Mn}$, Sand $\mathrm{Cu}$, and the corn dies during the blossom period. In 1990 some experiments to feed with multi-elements the corn land have been carried on; the feed corn grew very well and the yield increased $25 \%$ than before. 


\subsection{Change of the rural energy system}

The traditional rural energy is from the trees on the karst hills. The annual rural fuel requires $108,000 \mathrm{~m}^{3}$ of wood, but the annual products of the forests in Xichou karst is about $60,000 \mathrm{~m}^{3}$ of wood. So it is clear that the farmers over-cut $48,000 \mathrm{~m}^{3}$ of wood resource as fuel. Therefore it is necessary to improve the ecological system by reducing the fuel consumption. If the wood resource consumed as fuel has to be decreased to less than $60,000 \mathrm{~m}^{3}$, the ecological system will improve year by year. There are several ways to reduce the consumption of wood fuel: by reforming the traditional stoves to energy-saving stoves; by using electric energy from small scale hydropower stations; by developing gas energy; by distributing to the local people fossil chemical energy like the natural gas and the coal.

\subsection{Scientific development of water resources}

The "fengcong" landscape areas are usually short of water resources for irrigation for agriculture and water supply for human and livestock. In order to promote a sustainable development of agriculture and to solve the water supply problems the following techniques may be adopted:

\subsection{1 - Construction of water tanks or pools}

This is an efficient solution to accumulate the rain water and the runoff water, if it is possible to store the water of the temporary springs of the epikarst. This technique has been spread in the karst areas. By storing the runoff water during the rain period in double level tanks it is possible to separate the clear water in the second tank for water supply.

3.5.2 - Construction of underground reservoirs in suitable sites along the subsurface river or conduit flow

A dam may be built to seal or block the conduit or river flow; a semi-closed reservoir or complete closed reservoir is then obtained. If there are no flood problem for farm land and villages in the upper stream, a closed reservoir may be considered. For example, a $6 \mathrm{~m}$ high dam with a base $9 \mathrm{~m}$ long and $3 \mathrm{~m}$ thick and a top $1.8 \mathrm{~m}$ thick was built on the Yuezhai subsurface river near the outlet. It floods 3 depressions on the upper part. About $40,000 \mathrm{~m}^{3}$ of water are collected and 200 ha of rice field have been irrigated. The rice output per $m u$ rose from $200 \mathrm{~kg}$ before 1975 to $600 \mathrm{~kg}$ after 1996.

\subsection{3 - Construction of pumping stations}

A pumping station may be built above underground river and karst ponds. On account of the strong fluctuation of the karst water level, the pump may be installed, e.g., on a boat. A pump was installed on rails into the karst water occurrence of Disu Subsurface Drainage in Lengguo, Duan, Guangxi. If the water level rises above a given value, the pump station may be moved into a sealed pump house.

\subsection{4 - Construction of surface reservoirs}

Surface reservoirs suffer commonly of leakage problem. If a cement curtain is 
made around the dam, it is possible to obtain reliable reservoirs in karst basins and large depressions. In Dushan County, Guizhou181 pumping stations were installed up to irrigate $17,940 \mathrm{mu}$ of rice field.

\section{REFERENCES}

CHEN S., 1954 - Karst geomorphology in Southwest China. Geographic Knowledge, No.3.

CHOU R., 1988 -Preliminary study of the environmental strategy in the poor mountainous area of karst terrain in Guizhou. In: Guizhou Society of Environmental Sciences, A Study on the Karst Environment in Guizhou. Guizhou People's publisher: 44-49.

FORD D., 1997 - Preface. In: SONG L. et al (ed.), Stone Forest, A Treasure of Natural Heritage. China Environmental Science Press, Beijing: 1-4.

LU Y., 1976 - Karst in China (Picture album). Shanghai Scientific and Technical Publisher.

SONG L., 1981 - Progress of karst hydrology in China. Progress in Physical Geography. 5 (4): 563-574.

SONG L., 1986 - Karst geomorphology and subterranean drainage in south Dushan, GuizhouProvince, China. Cave Science 13 (2): 49-63.

SONG L., 1991 - The comprehensive study of water, land, biological resources in karst fengcong area in Xichou County, Yunnan. (Technical Report in Chinese).

SONG L., 1997 - Development and ecological-environment in karst areas. Conference on Geomorphology and Environmental Education across the Taiwan Strait, Tainan: 197-201.

SU Z., 1993 - Agro-ecological economic structures in karst area in Guangxi. In Approach of Agriculture Development in Karst areas in China, Proceedings of National Symposium on the Agriculture Development in Karst Areas, Guiyang: 113-118.

YANG H., 1988. - The fragile karst environment. In: Guizhou Society of Environmental Sciences, A Study on the Karst Environment in Guizhou. Guizhou People's Publisher: 15-18.

YANG M., HE C., 1976 - The basic features of geomorphological development in Guizhou. Guizhou Geological Scientific and Technical Informations, No.2: 44-67.

YANG M., 1988 - On the regional structure and environmental effect of the karst landform. In Guizhou Society of Environmental Sciences, A Study on the Karst Environment in Guizhou: 19-26.

YUAN D., ZHU D. et al., 1991 - Karst of China. Geological Publishing House, Beijing.

ZENG C. et al., 1960 - Preliminary study of karst geomorphologic types in Fenglin areas, South China. Geografica Sinica, 26 (1): 45-51.

ZENG C., 1964 - Some problems on karst geomorphological types in South China. Geologica Sinica, 44 (1): 119-128.

ZHANG F., SONG L., 1993 - Research on ecological environment and Sapium Rotundifolium in karst area of Southeastern Yunnan. Carsologica Sinica, 12: 85-90.

ZHANG S. et al., 1979 - Study of Karst in China. Science Press, Beijing.

ZHAO J., 1988 - Preliminary study on conservation of the karst ecologic environment. In Guizhou Society of Environmental Sciences, A Study on theKarst Environment in Guizhou. Guizhou People's Publisher: 44-49.

ZHOU H., 1965 - Characters of China Karst. No.2: 60. 